\title{
Free Sunday Campaign \\ A Case Study from Croatia
}

Enoh Šbeba*
enoh.seba@tfmvi.hr https://doi.org/10.31192/np.17.3.10

UDK: 27-563:331.311

$272-4: 272-722.7$

Izvorni znanstveni rad / Original scientific paper

Primljeno / Received: 26. svibnja 2019. / May 26, 2019

Prihvaćeno / Accepted: 21. kolovoza 2019. / Aug 21, 2019

The intent of this article is to evaluate the course of Free Sunday Campaign - the advocacy initiative originally launched in 2003 by Croatian Caritas and Franciscan Institute for the Culture of Peace and later joined by a number of major trade unions and Centre for the Promotion of Social Teaching of the Church. The author seeks to analyse its proceeding by considering theological and ethical reasons that prompted its launch, to present its operational methodology, and to explore its intended and achieved goals. An aftermath period between 20092019 is also taken into account, including the foundation of Croatian Sunday Alliance as an effort to revive the Free Sunday cause. Toward the conclusion, the author argues that this Campaign successfully served to pave the way for other socially engaged initiatives based on the participation of lay believers and citizens, although there might be some significant differences between them concerning their cohesive potential for the Croatian society at large. Finally, the author also posits that Campaign managed to indicate that authenticity of Catholic Church social presence will depend on the engagement of lay believers, on effective promotion of solidarity with the exploited and on healing (rather than divisive) nature of its pursuits.

Keywords: Free Sunday, Croatian Sunday Alliance, voluntarism, solidarity, lay participation.

\footnotetext{
* Enoh Šeba, PhD, secretary of Centre for Protestant Theology Matthias Flacius Illyricus, University of Zagreb; Address: Ivana Lučića 1a, HR-10000 Zagreb, Croatia.
} 


\section{Introduction}

Before I proceed with presenting this study case, it is necessary to make note that the majority of this text came into being as I prepared for Lutheran World Federation European Consultation, held in Budapest, June 26 - 29, 2009. The title of the entire event was 20 Years After the System Change - Church and State in Societies in Transformation. The topic of my presentation focused on Free Sunday Campaign that at that point has come a full circle. After initial success, the legislation changes in 2009 apparently nullified the Campaign's efforts and outcomes. Nevertheless, that case served as a useful material for reflection on the complex and fragile nature of relationships between Church, state and community at large within the Croatian society as a transitional society. Since this presentation has never been published as a paper, my goal here is to revise its original content with a reassessment of the Campaign's course and results from a vantage point of ten years of distance. Readers should thus keep in mind the fact that only the last section of this article was written from a contemporary perspective while the rest of the text originated from the period during or immediately after the Campaign.

\section{Free Sunday Campaign - A Chronological Overview}

According to the available data, 12 per cent of all Croatian employees work in the trade sector, and 75 per cent of them are women. ${ }^{1}$ In 2003 , various sources indicated that between 30 and 40 thousand workers were regularly working on Sundays, although the Labour Law allowed Sunday work only »in case of necessity « (article 38). ${ }^{2}$ Trade unions were repeatedly warning the public that various workers' rights were continuously being violated - such as the right to a day of rest, the right to paid overtime work, the right to receive a supplement for working on Sundays (35\%) or holidays (50\%). The consequences of these violations were various and among them, blocking the opportunities for unemployment decrease or the negative effects on the family and social life of employees, especially women, should be particularly emphasized. Due to the fear of losing their jobs, workers would rarely protest and claim their rights, knowing that they were easily »replaceable«. Commenting on this situation in the society, Catholic theologian Željko Tanjić observed, »It seems that, according to some people's opinion, liberal democracy and capitalism mean that

\footnotetext{
${ }^{1}$ Igor BERTOVIĆ, »Ekonomski aspekti rada nedjeljom « in Stjepan BALOBAN and Gordan ČRPIĆ (eds.), Kultura nedjelje i dostojanstvo radnika, Zagreb, Centar za promicanje socijalnog nauka Crkve and Kršćanska sadašnjost, 2005, 37-47: 43.

2 Zakon o trgovini (Narodne novine, 38/1995, 54/1995, 65/1995, 17/2001, 82/2001, 114/2003, $142 / 2003)$
} 
only one segment of society does not need regulations and rules, and that is the market. $\aleph^{3}$ Early in 2003, five years after Sunday trading had become a standard practice rather than the exception, several different organizations decided to launch a joint campaign in order to force the Croatian Parliament to pass amendments to the Labour Law that would ban Sunday trading.

\subsection{Initiators of the Campaign}

The original initiators of the Campaign were Hrvatski Caritas (Croatian Caritas) and Franjevački institut za kulturu mira (Franciscan Institute for the Culture of Peace). A number of major trade unions collaborated with these two church-related organizations (Sindikat trgovine Hrvatske, Hrvatska udruga sindikata, Savez samostalnih sindikata Hrvatske, Nezavisni hrvatski sindikati...). However, support has also come from some professional organizations - Croatian Chamber of Trades and Crafts and Croatian Employers' Association. During the second stage of the campaign, a third Catholic organization got involved - Centar za promicanje socijalnog nauka Crkve (Centre for the Promotion of Social Teaching of the Church). In order to understand their influence and roles, we must now proceed to a short overview of the Campaign's course.

\subsection{Main developments during the period from 2003-2008}

In April 2003, Croatian Caritas and Franciscan Institute for Culture of Peace initiated the signing of a petition called Sunday Trading Means Human Trafficking. The first sentence of the petition says, »In the name of human dignity, of human, workers' and religious rights, we ask the Parliament and the Croatian Government to enact a law that would ban all trading on Sundays and holidays. $\aleph^{4}$ Petition forms were distributed throughout the country (in 80 towns and over 1.400 Catholic parishes) and in thirty days, over 300 thousand citizens signed the petition. Simultaneously, intensive lobbying was taking place, since the representatives of the Campaign initiators managed to meet with several government ministers and various Members of Parliament. ${ }^{5}$ Msgr. Ivan Prenđa, in his capacity as the president of Hrvatski Caritas and the vice-

3 Željko TANJIĆ, Nedjelja ili 'Shopping Day' in Stjepan BALOBAN and Gordan ČRPIĆ (eds.), Kultura nedjelje i dostojanstvo radnika, Zagreb, Centar za promicanje socijalnog nauka Crkve and Kršćanska sadašnjost, 2005, 65-70: 65-6. All translations of quotations from Croatian sources are mine.

${ }^{4}$ Hrvatski Caritas and Franjevački institut za kulturu mira, Peticija Vladi i Saboru Republike Hrvatske, May 2003. The only exceptions suggested in the text refer only to grocery shops and only during the tourist season.

${ }^{5}$ The only political party that expressed public support to the Campaign was the Croatian Peasant Party, whose President, then President of the Parliament, handed in the signatures of the Party's officials on 28 May, 2003. 
president of Hrvatska biskupska konferencija (Croatian Bishops' Conference), delivered signatures to the Prime Minister Ivica Račan on 8 September 2003. Finally, this resulted in the Parliament's activity in preparing a bill which in the end was adopted among the amendments and appendices to the Trading Law $^{6}$ on 21 October 2003 and was to come into effect on 1 January 2004.

However, seven chains of retail stores lodged a constitutional complaint even before the bill had become effective. In addition, the director of the International Monetary Fund's mission in Croatia, Hans Flickenschild, exercised additional pressure by releasing a statement in which his institution opposed the banning of Sunday trading. . The eventual outcome was that less than four months after its introduction, the Constitutional Court decided to repeal the law on the grounds of being discriminatory in terms of size of shops that were allowed to be open on Sundays.

Already anticipating such a development, on 10 March 2004, the Croatian Bishops' Conference summoned the Croatian Caritas, the Center for the Promotion of Social Teaching of the Church and the Franciscan Institute for the Culture of Peace to draw up a document on the problem of Sunday trading. There already was a message on the Christian meaning and celebration of Sunday, issued by the Croatian Bishops on June 10, 1997, ${ }^{8}$ but at that moment the need arose to upgrade and heighten the discussion. The case for free Sunday demanded a stronger and more comprehensive argument, which would be presented from the economic, social, anthropological, and cultural perspective. The resulting text, entitled Nedjelja radi čovjeka (Sunday for the sake of people $)^{9}$ was presented in April 2004, together with the results of a comprehensive survey, according to which 70 per cent of the population was expressing support to the amendments and appendices to the Trading Law, while only 17 per cent had explicitly given their vote against them. ${ }^{10}$ Another written expression of advocating the special status of Sunday occurred in the form of Izjava o осиvanju kulture nedjelje (Statement on the protection of Sunday), created by the Iustitia et pax commission of the Croatian Bishops' Conference on 19 January 2005. Its particular purpose was to contribute to the adoption of a new Trading Law that would protect both the culture of Sunday and the workers' rights of those employed in the trading sector.

\footnotetext{
${ }^{6}$ Full text available at http://narodne-novine.nn.hr/clanci/sluzbeni/307038.html (12.05.2019).

7 Marinko PETKOVIĆ, Izjava Hansa Flickenschilda iznenađuje, a doima se kao diktat [Hans Flickenshild's Statement is a Surprise, and Looks like a Dictate], Vjesnik, December 9, 2003, 7, http://ns1.vjesnik.com/pdf/2003\%5C12\%5C19\%5C07A7.PDF (18.05.2009).

${ }^{8}$ Biskupi o nedjelji, http://www.ffdi.hr/mep/06-euharistija/biskupi_o_nedjelji.htm (17.05.2009).

${ }^{9}$ Hrvatska biskupska konferencija, Nedjelja radi čovjeka, Zagreb, Hrvatska biskupska konferencija, 2004.

${ }^{10}$ Stjepan BALOBAN, Gordan ČRPIĆ and Marijana KOMPES, Centar za promicanje socijalnog nauka Crkve. Deseta obljetnica djelovanja (1998.-2008.), Zagreb, Centar za promicanje socijalnog nauka Crkve and Kršćanska sadašnjost, 2008, 160.
} 
In the next three years, the Campaign aimed at raising the political awareness of the issue, although the process was very slow and the politicians were often hesitant in meeting with the Campaign's advocates. During this stage, the line of reasoning relied on two documents mentioned above and a somewhat wider spectre of arguments was pursued - the protection of workers' dignity, the promotion of family, the economic argument, the cultural argument, and the results of the petition. ${ }^{11}$ Eventually, these steady endeavours proved efficient and a new Trading Law was adopted by the Parliament in July 2008. ${ }^{12}$

The new law came into effect early in 2009. The exceptions to the ban were better specified, while the control and inspection mechanisms were more easily enforceable than in 2003. However, the beginning of implementation was accompanied by mainly negative media coverage. Newspaper and television channels tended to report on this issue chiefly through the lens of power relations. Employers and shop owners often complained against the ban, claiming that together with the recession, it caused 7000 people to lose their job. As a matter of fact, several chains of retail stores had already lodged another constitutional complaint, claiming that the law implied disrespect for market freedoms and a »violation of the legitimate expectations of people who have invested hundreds of millions of Euros in building shopping malls and supermarkets. ${ }^{13}$ Finally, very recently (June 19, 2009), the Constitutional Court issued a new decision by which a Law was abolished again. ${ }^{14}$ In spite of the relatively unsuccessful legislative situation, in order to become more competent and fully understand the present state of affairs, we must now turn to a more detailed investigation of the Campaign from a specific point of view, which is the standpoint of Christian ethics.

\section{Campaign analysis from the perspective of Christian ethics}

Before I proceed to the actual interpretation of the Campaign's ethical fabric, a preliminary remark are needed. Even though Catholic organizations and individuals have been repeatedly using arguments that would not be extraneous to other Christian traditions, there have been no official statements, reactions, or other responses from non-Catholic Christian churches. ${ }^{15}$ To provide an ad-

\footnotetext{
${ }^{11}$ Ibid., 163.

${ }^{12}$ For a full text, see Zakon o trgovini, Narodne novine (87/2008), https://narodne-novine.nn.hr/ clanci/sluzbeni/2008_07_87_2790.html (10.04.2019.)

${ }^{13} \mathrm{http} / / /$ www.suvremena.hr/10235.aspx (11.04.2009).

${ }^{14}$ For a full text, see http://www.obrtnicka-komora-rijeka.hr/images/stories/ceh_trgovine/odluka_us.doc (12.04.2009).

${ }^{15}$ According to the last census (2011), Catholics constitute $86.28 \%$, Ortxhodox $4.44 \%$, and all Protestants together $0.34 \%$ of entire Croatian population. https://www.dzs.hr/Hrv/censuses/ census2011/results/htm/usp_04_HR.htm (10.03.2019).
} 
equate answer(s) why this has been so, I would need to move beyond the scope of this essay. Thus, my analysis here will primarily take into account Christian ethical stances as expounded by the Catholic advocates of the Campaign.

\subsection{Motivation - theological and ethical elements}

Apparently, this Campaign was deep-seated in a specific rationale - a web of theological and ethical reasons which prompted its initiators to act. Of course, there is a strong theological argument - God has taken a rest on the seventh day (Gen 2:3). Croatian bishops interpret this move as a decision »to be with himself«, that is, in the Trinitarian relationship. Consequently, if one human being desires a quality relationship with another, he or she must first meet himself/herself, which for a believer necessarily includes a relationship with God. ${ }^{16}$ By celebrating the seventh day, a human being acknowledges God's sovereignty over him or her and all creation. Furthermore, because of the resurrection, it is possible to maintain that Sunday represents »both 'the first' and 'the last' day of the week: the celebration of existence and its renewal, recreation in a theological and biological sense. $\aleph^{17}$ Advocating Sunday, therefore, means supporting »the freedom of a human being, his or her other dimension, the possibility to be in another way, different from that which is defined by employment. ${ }^{18}$ This insistence on the transcendent dimension of Sunday emphasizes the universal human need for renewal and underlines the Christian belief that human existence is not to be reduced to the processes of production and consumption, especially in the light of the promise of eternal life. Actually, freedom of Sunday allows people to question the meaning and sense of everyday work and everyday affairs. Finally, the bishops urge their believers to protect the Christian meaning of Sunday, not only for their own benefit but also for the benefit of all their co-citizens. By their involvement in Sunday church activities, they are becoming »the mediators of blessing for the wellbeing of the entire community. ${ }^{19}$

\footnotetext{
${ }^{16}$ Hrvatska biskupska konferencija, Nedjelja radi čovjeka..., 12.

${ }^{17}$ Ibid., 15.

${ }^{18}$ Ibid., 13.

${ }^{19} \mathrm{Ibid}$., 45. It could be rather advantageous to correlate this specific instruction with the concept of »vicarious religion", introduced by sociologist Grace Davie. See her Religion in Modern Europe: A Memory Mutates, Oxford, Oxford University Press, 2000. She defines it as »the notion of religion performed by an active minority but on behalf of a much larger number, who (implicitly at least) not only understand, but, quite clearly, approve of what the minority is doing." Davie continues by discussing how religion can operate vicariously in various ways, and mentions the possibility that churches »can offer space for the vicarious debate of unresolved issues in modern societies. " [Grace DAVIE, Religion in Europe in the 21st century: the factors to take into account. European Journal of Sociology/Archives Européennes de Sociologie, 2 (2006) 271-296: 273]. Could it be that the campaign for Free Sunday in Croatia is one of those
} 
Parallel to this theological line of thought, there is an ethical argumentation. Addressing the business people, the bishops speak of human dignity inherent to both employers (or superiors) and the common people. Those of higher rank should be aware that they also have needs of the common people and that the greatness of a person's dignity and humanity is proportionate to honouring the common human needs, both in others and in oneself. ${ }^{20}$ Free Sunday contains a component of the development of the culture of peace, which is tremendously significant in a society burdened by violence, which is a result not only of the recent war turbulences but of the post-war and post-communist period marked by instability. However, in order to be able to build such a culture, a specific day is needed, a day that is not intended for having more, but for being more. ${ }^{21}$

It is fairly evident that these ethical considerations are intertwined with the social dimensions of stimulus which instigated this campaign. Deriving from the Jewish, Old Testament concept of Sabbath, Christian Sunday always had a prominent social facet - to protect the common people from labour exploitation. ${ }^{22}$ The institution of Sunday served to remind that every human being, among other basic needs, has the need for a rest. Observing Sunday in that way protects the equality of all people, treating everyone primarily as a person. But it is important to take note of another social aspect: it is not only an individual who rests on Sunday; it is the entire community that rests, too. When the whole society steps out of the ordinary routine of the week, that results in breaking the logic of scores and usefulness, the logic of product exchange and consumption, and an interesting social experiment begins: what will happen when the wheel of the economy is stopped? ${ }^{23}$

However, the current global trends strive to depersonalise the individual human being and to reduce him or her to the role of a small part in the process of weekly production and Sunday consumption. This reduction is possible inasmuch as the concept of wellbeing is redefined and diluted to the meaning of merely material wellbeing. But wellbeing in itself is holistic, and as such it requires »creative peace distanced from permanent everyday requirements «. ${ }^{24}$ Only then the other sides of wellbeing will be given space to develop unchallenged, and only then the material wellbeing is more likely to become long-lasting.

Another way of addressing the same social problem is to discuss it in terms of »freedom«. Tanjić has finely presented its gist by saying that

»unresolved issues « which society is unwilling to work on, and therefore tacitly asks the church to bring it up?

${ }^{20}$ Hrvatska biskupska konferencija, Nedjelja radi čovjeka..., 41.

${ }^{21}$ Ibid., 34-35.

${ }^{22}$ A brief, but useful overview of concept of rest in Jewish and Christian belief can be found in Mato ZOVKIĆ, Spomen Božjih djela - zalog nade u sigurnu budućnost, Bogoslovska smotra, 67 (1997) 171-189; https://hrcak.srce.hr/32086 and Marijan VUGDELIJA, Božje zapovijedi. Putokaz autentičnog življenja i danas?, Makarska, Franjevačka visoka bogoslovija, 1989, 2-28.

${ }^{23}$ Tanjić, Nedjelja ili 'Shopping Day'..., 68-9.

${ }^{24}$ Hrvatska biskupska konferencija, Nedjelja radi čovjeka..., 14. 
»freedom is possible only as a sum of variously perceived freedoms of individual fields, such as market, politics, religion, art, science. That also demonstrates the fact that the neoliberal understanding of freedom as exclusively market freedom can only lead to the utter impoverishment and partial understanding of freedom which is one of the greatest achievements of our civilization and culture ${ }^{25}$

Therefore, even if malicious observers interpret the campaign as an attempt of the Church to bring people back to churches, their comments nevertheless affirm the claim of the above argument - namely, that there are other "freedoms « and that the market freedom may clash with religious freedom today, but tomorrow's obstacle might, for instance, be freedom of science.

Last, but not least, it is quite possible that the zealousness of some church ranks during this Campaign came out of the frustration caused by the growing and seemingly unstoppable secularization made a rather evident expansion of consumerism perpetuated by aggressive Sunday trading. Hence it is not completely unlikely that some church officials and a certain proportion of »ordinary« believers have also identified Free Sunday cause with the strategy for getting people back to church buildings or with preventing a further drop in church attendance.

\subsection{Method}

Now, apart from discerning the motivation behind it, the proper Campaign evaluation must include overviewing methods employed during its course. Even though the problem of Sunday trading was already present in the Croatian society several years ago, it was not clearly visible in public opinion. Therefore, the preparation of the Campaign included survey research, and a PR agency was engaged for planning its course (including the way of presenting the research results). ${ }^{26}$ The following step was petition-signing, organized in three different settings in order to reach diverse target groups: on city squares, in front of church buildings after the services, and in trade-union headquarters. Various kinds of accompanying advertisements in the mass media were conceived with a similar idea: to raise the awareness of the problem and to "make it real« by bringing it to the forefront of public consciousness. The essential motive was to gain the widest possible support to the cause of Campaign.

However, another mode of operation targeted the decision-makers. Intensive meetings with trade union and other social partners were arranged in order to prepare adequate amendment proposals. Continuous lobbying among the members of Parliament, ministers and a number of party officials, mobilisation

\footnotetext{
${ }^{25}$ Tanjić, Nedjelja ili 'Shopping Day'..., 67-8.

${ }^{26}$ Vice BATARELO, Vice-President of Croatian Caritas, interviewed by author, 15 March 2009, Zagreb.
} 
of parish priests and church-related organisations, and constant reminding of bishops that they should exercise their influence in communicating with the representatives of secular authorities - all these things sometimes required much more energy and time than the initial steps aimed at the general population. Also, the progress was not that easily noticeable, and indifference, or even opposition, was much more frequent.

During the later stages of the Campaign, notable attention was paid to drawing up official documents in order to reinforce the Church's argument within the specific context and time. Those documents were meant to justify the demand for the institutional protection of Sunday. ${ }^{27}$ Also, their purpose was to suggest a set of guidelines which would steer the adoption of the new Trading Law. ${ }^{28}$ In the same time, they recognized the need for some services to be available on Sunday but emphasized the need for a proper acknowledgement and reward for those employees.

And last, but not least, the Campaign received ongoing prayer support some monastic communities prayed devotedly for the course and the outcomes of the Campaign.$^{29}$ However, before we turn our attention to the actually accomplished outcomes, we will benefit from a concise summary of the intended goals.

\subsection{The intended goals}

The most apparent goal of the Campaign has been to achieve the institutional protection of free Sunday. One of the explanations why such protection is sought says that there were countless manipulations of that freedom. For example, »Through the influence of marketing the consumerist society attempts to maximize the material gain from the human need for the rest $\iota^{30}$ By banning Sunday trading, more space would be created to talk and discuss Sunday for the people, perceived as a part of European cultural heritage. To different objections that free Sunday is "useless « in the market sense, the Campaign's advocates reply that free Sunday is genuinely useful, since

»it defines the limitations of the market and profit so that other domains of social life, such as culture, art, religious and other traditions, religious and other events and celebrations, will not be endangered ${ }^{31}$

\footnotetext{
${ }^{27} »$ In the same way in which the human right to labour is institutionally protected, the right to rest on those days when the majority of the society is taking rest (and within the European civilizational order this day is Sunday) should be institutionally protected as well« (Hrvatska biskupska konferencija, Nedjelja radi čovjeka..., 29).

${ }^{28}$ For example, Izjava... lists ten facts to be kept in mind while composing a new Law - most of them related to the need for the new Law to be clear, enforceable, and without exceptions.

${ }^{29}$ In his interview, Batarelo has mentioned a specific community of Carmelite nuns.

${ }^{30}$ Hrvatska biskupska konferencija, Nedjelja radi čovjeka..., 27.

${ }^{31}$ Ibid., 30.
} 
Although the media have primarily focused on this goal, and most of the debates revolved around the arguments for and against such institutional protection and its potential consequences, there was another major objective which was probably somewhat less observed by the wider community. The purpose of the Campaign was also to encourage participation in the society that would contend and surpass usual passivity that prevailed in the Croatian public sphere and the deeply held conviction that nothing could ever be positively changed on the level of the society at large..$^{32}$ With respect to that responsibility for the human community, in which all individuals live, the Campaign aimed both at the laity in the church and at the citizens as members of the civil society. ${ }^{33}$ This idea was reflected in the stimulus directed at the believers in influential organizations who were supposed to advocate for free Sunday, but who

»should not be content with the political and social protection of Sunday, but should also and primarily live out its values, both Christian ones and more general, human and cultural ones «. ${ }^{34}$

From the standpoint of Christian social ethics, it seems vital to take notice of the fact that such twofold intent implies that the Church's responsibility for the society is fulfilled not only through institutional methods and structural changes, but also through the practical involvement of individual believers and local communities, and the application of faith in everyday life. In other words, the Campaign's ambition has been to make a difference within the society at large, but this difference is closely related to the transformation of the Church itself. Another way of expressing this would be to claim that any change at the institutional level is unsustainable without the support of faith communities in which the life of every single believer is a place where change is expected. In that respect, this Campaign could be perceived as a pioneering attempt to pair the enthusiasm of individuals believers who wanted to live out their specifically Christian convictions and apply them in a particular social context and voluntarism of other individuals and groups who are ready to stand for the common welfare because of their humanist values.

\footnotetext{
${ }^{32}$ This passivity seems to be, at least partly, a legacy of living under the Communist system, where people would unmistakably perceive injustice and discrimination, and privately resent against them. But they would rarely or never decide to publicly act against them because the institutional and structural framework was built in a way that discouraged such attempts. Subsequently, even nowadays can be argued there is a strong distrust toward authorities and claiming justice through institutional channels or initiatives of civil society. Cf. Stjepan BALOBAN and Ivan RIMAC, Povjerenje u institucije u Hrvatskoj, Bogoslovska smotra, 4 (1998) 663-672; https://hrcak.srce.hr/31611.

${ }^{33}$ Vice BATARELO, Vice-President of Croatian Caritas, interviewed by author, 15 March 2009, Zagreb.

${ }^{34}$ Hrvatska biskupska konferencija, Nedjelja radi čovjeka..., 45.
} 


\subsection{The accomplished outcomes}

I believe it is fair to assert that the entire initiative has been a combination of lay enterprise, which tried to stimulate »ordinary« believers across the country, and the influence of Church hierarchy through lobbying and dialoguing with the government and the parliament. But it is also reasonable to state that one of the crucial elements for the Campaign's success has been the recognition that church-related organizations need support from other segments of society - including trade unions and employers' organizations - as well as the presence in the media. Regarded from this perspective, it can be concluded that the Campaign has managed to raise the problem of violating worker' rights, manifested in Sunday trading, to the level of a national issue and has succeeded in creating consensus across the social spectrum.

To be sure, the ban on Sunday trading, especially the one that was effective until recently, is a self-evident outcome of the Campaign. But this fact points to the readiness of ppolitical structures to cooperate with the civil society and to accept the will of citizens $« .{ }^{35}$ The reverse side of it, however, is the »lack of citizens' experience in getting involved in the civil society «. ${ }^{36}$ If the entire course of the Campaign is taken into account, it seems that both the beginning and the future of the Campaign heavily depends on solidarity among the community members. It is the solidarity with the (mostly) female workers in shops, whose rights are continuously violated, which has led to a strong response to the petition and created an early pressure on the policy-makers. It is the solidarity again that will be a requisite for extending the Campaign's effects beyond mere institutional protection and in developing a "free Sunday» that will authentically promote the comprehensive development of both the community and the individual people, uninhibited by the rush of the market and the profit-oriented worldview. And it is the solidarity that will keep the church believers mobilized and willing to express their personal beliefs in accordance with the social teaching of the Church, thus countering the effects of their living out their Catholicism as a "vicarious religion" (as defined by Davie).

Ultimately, the Campaign has surely revealed general ineffectiveness of the Croatian society, which mainly stem from the faulty functioning of the legal system. ${ }^{37}$ But at an even deeper level, we could ask ourselves, together with Tanjić who points to the confusion regarding the issue of what really defines the identity of the Croatian society - do we indeed advocate an identity that perceives the human exclusively as an economic being, as a consumer? If so, he proposes rather ironically, then Sunday should be renamed to »a shopping day«!38

\footnotetext{
${ }^{35}$ Ibid., 11.

${ }^{36}$ Ibid., 26.

${ }^{37}$ Cf. ibid., 19-26.

${ }^{38}$ Tanjić, Nedjelja ili 'Shopping Day'.., 69-70.
} 


\section{Ten years later}

At the present moment, we are given the luxury to reassess the Campaign from a temporal distance. After the abolishment of the law in 2009, a period of relative silence followed. The entire issue of Sunday work regulation recessed from the public space and it appeared that the main initiators of Campaign ceased to press on with their cause. There is no clear explanation of why they decided to drop the matter when they could have initiated another amendment proposal using the experience of previous two attempts and the benevolent public opinion. Still, the Campaign itself may have never been relaunched, but some advocacy efforts were still being made during these last ten years.

So, this inactivity was not disturbed before 2014 when a book called Free Sunday: A Disappearing Culture? was published by Centre for the Promotion of Social Teaching of the Church, Kršćanska sadašnjost (a key Catholic publisher), Franciscan Institute for the Culture of Peace and Croatian Catholic University. ${ }^{39}$ This title presented the results of empirical research and eight essays arguing for the free Sundays from a variety of perspectives and offering different perspectives. However, no practical steps were taken as a follow-up until April 2018 when a Croatian Sunday Alliance was founded and joined by representatives of 14 different religious communities, academic institutions, trade unions and NGO's. As a non-profit association, this Alliance focused on the protection of Sunday as a work-free day and dignity of work and invited organisations of civil society, trade union movement, socially responsible employers, churches and other religious communities to collaborate on promoting these causes and calls upon political parties to take necessary steps to accomplishment of those goals. ${ }^{40}$

Another attempt of reviving the Sunday theme was making a documentary Seventh Day (directed by Boris Orešić). The idea of this film was to illustrate the terrible personal experiences of workers forced to work on Sundays and to contrast these with the current practice in Austria. President of Franciscan Institute for the Culture of Peace, Bože Vuleta, OFM, said that the film's basic message is that Sunday trading is

"unnecessary, detrimental to workers' health, threatening to the cohesion of the family and society, economically unjustified and unsustainable in the long run. Therefore, the existing practice has to be changed «. ${ }^{41}$

\footnotetext{
${ }^{39}$ Marija BELOŠEVIĆ, Predstavljena knjiga: Slobodna nedjelja - kultura u nestajanju? (29.05.2014), http://franjevacki-institut.hr/aktivnosti/radnici/predstavljena-knjiga--slobodnanedjelja-kultura-u-nestajanju-/9 (18.05.2019).

${ }^{40}$ Founding Statement, http://franjevacki-institut.hr/sadrzaj/pdf/2018-03-14-13-51-8757-.pdf (22.05.2019).

${ }^{41}$ Fra Božo Vuleta: Rad nedjeljom razara obiteljske odnose, a žene su najpogođenije, http://misija.slobodnadalmacija.hr/clanci/id/33295/Fra-Bozo-Vuleta-Rad-nedjeljom-razara-obiteljskeodnose-a-zene-su-najpogoenije (17.05.2019).
} 
However, the first significant event organised by the Alliance (and supported by Konrad Adenauer Foundation) was an international conference Culture of (Work-Free) Sunday. It was held at Croatian Catholic University in November 2018 and participants tried: to pinpoint the negative effects of absence of Sunday trading regulation; to present the relevant data from various studies dealing with working on Sundays both in Croatia and European Union; to introduce experiences of members of similar alliance from Austria and to point to the inadequacy of European legislation in this area. Also, the representatives of several chain supermarkets publicly confirmed their readiness to support the Free Sunday initiative.

Finally, in February 2019 a conference called Free Sunday and working hours dignity in Europe: How to move on? was held in European Parliament, in Brussels. ${ }^{42}$ The crucial purpose of this meeting was the sharing of the examples of good practice from various European countries and activities of their respective national alliances. Several representatives of Croatian Sunday Alliance took part in this conference, including some trade union members. Marijana Petir, a Croatian MEP, referred to two field studies in order to signify that $90 \%$ of Croatian citizens would approve free Sunday while $50 \%$ of all employed citizens work extra hours, especially in trading.

So, where does this leave this entire cause and can we infer anything about possible future developments from how this initiative worked out in the past?

\section{What have we learned?}

First of all, it is hard to ignore the overall impression that the Free Sunday cause gradually faded into the background in spite of more recent activities mentioned above. Its advocators do not seem to have the same success in bringing this issue to the forefront of public discourse (as they used to, back in 20032009 period). As shown earlier, the original Campaign has been mindfully designed to lay out its arguments on the basis of promoting workers' rights, family values, work-life balance and shared leisure time, rather than merely on the ground of religious freedom to worship on a day that is relevant within a specific religious tradition. The reasoning during the last ten years even more meticulously followed such orientation and yet the wider appeal and consensus among different ranks of society is missing. Apparently, there is no obvious and straightforward explanation - however, given the dominant trend of polarisation in Croatian society, it might be profitable to adequately look into questions such as: Are there other, more ideologically charged issues that are more likely

\footnotetext{
${ }^{42}$ Hrvatski savez za nedjelju predstavio se u Europskom parlamentu (19.02.2019), http://www. petir.eu/novosti/hrvatski-savez-za-nedjelju-predstavio-se-u-europskom-parlamentu/9005 (19.05.2019).
} 
to attract attention and recruit committed activists? Have these causes gradually overshadowed the significance of Free Sunday campaign? Could it also be that these other aims are more »cost-effective« enterprises that can be employed in a larger scheme of power games within the Croatian political realm?

Surely, the Church has often been accused of »meddling in politics« during recent years and there is a lot of misunderstanding concerning the Christian institutional and individual engagement in society ${ }^{43}$. Nevertheless, I believe that this Campaign has proven that church members can have their say in social issues and that their voice can be successfully articulated. It paved a way for some later campaigns and confirmed there are effective ways of advocating and lobbying for institutional regulation of critical issues. What is intriguing, though, is the choice of ethical questions that initiated those campaigns and their accompanying repercussions.

The two most evident and most effective examples are the initiative related to the referendum on marriage and the movement that advocates banning abortion. In 2013, a network of organisations under the umbrella of $\Perp U$ ime obitelji (On behalf of the family) managed to bring on the constitutional referendum on the definition of marriage in response to the government's proposal to legalize same-sex partnership. Their continuous endeavours, backed up by Church leaders and supported by prominent political leaders, led to the acceptance of the constitutional amendment that defines the marriage as a union of man and woman. In 2016, a rally called »Hod za život« (March for Life) has been held in Zagreb. It was organised by a number of pro-life and family organisations (including those involved in the marriage referendum initiative) and their goal was to create a political pressure to legally preserve the sanctity of life from conception and therefore to ban abortion. Their similar activities continue to the present day with the goal of influencing the public opinion and policymakers in Parliament who are obliged by Constitutional Court to write a new abortion law.

A neutral, observing outsider might have several questions to pose to this particular situation. Why these civil associations and church-related groups have not chosen to address other, at least equally pervasive and perhaps even more threatening social issues? For instance, the problems of corruption and nepotism are widespread problems that suspend the wellbeing of Croatian society for more than two decades now. ${ }^{44}$ Or, the urgency of reforming the existing pension system that is unsustainable due to the poor management

\footnotetext{
${ }^{43}$ As a response to this common accusation, Nedjelja radi čovjeka declares, »we are aware that the church institutions and associations of believers are not the first or the only factor in various social issues. The Church, however, does not want and is not allowed to renounce at her right and duty to offer her contribution«, 38.

${ }^{44}$ See, for instance, Jelena BUDAK, Corruption in Croatia: Perceptions Rise, Problems Remain, Privredna kretanja i ekonomska politika, 106 (2016) 66-98; https://hrcak.srce.hr/18396 and Dražen GLAVAŠ, Christian on Sunday and Atheist on Monday: bridging the faith and work gap
} 
and pursuit of short-term political and financial interests by those in power represents another burning issue. Both of these affect all social strata but those who are poor and/or underprivileged are especially vulnerable and affected. Furthermore, the detection of these problems would quite likely gain a general recognition and inspire a strong sense of solidarity (possibly similar to the one that provided momentum for Free Sunday Campaign). Therefore, would advocating for addressing these two causes create a more helpful, cohesive and healing force within this society? By contrast, it can be argued that the marriage referendum initiative and the pro-life movement, although quite efficient in accomplishing their purposes, create even more divisions within the larger community and contribute to the sense of polarising hostility on the national level. Whereas Free Sunday Campaign stood up for workers' rights, these two are frequently accused of violating different minority rights. Another puzzling detail could be the observation that the level of networking and cooperation with partners outside of Catholic and conservative background is relatively low when compared with the breadth of collaboration with various social protagonists achieved and promoted in Free Sunday Campaign and Croatian Sunday Alliance (trade unions, Croatian Chamber of Trades and Crafts and Croatian Employers' Association, different educational institutions, and faith communities other than Catholic Church). And one final observation can also be stated in the interrogative form: Why has Croatian Bishops' Conference ceased to lend its open and unequivocal support to Free Sunday cause? There is no doubt that the leadership of Catholic Church still believes in the sacredness of Lord's Day but it is still rather indicative that its patronage, at least at the present time, seems to be reserved for other socially engaged initiatives.

Is it possible, then, to anticipate the future of Free Sunday cause in Croatia? It is fairly easy to conclude that over the last ten years the pressure towards reliberalization of Sunday trading has been largely unchallenged. Multinational companies and trading chains have the international support and backup which trade unions usually do not and during the recession period, different indicators were occasionally presented as a proof that ban of any future ban on Sunday trading would have a number of negative effects on the national economy (increasing unemployment, decrease of production, etc.) Within such context and without restoring some of the premises of the original Campaign, I think that the chances of a future ban on Sunday trading can be described as slim at its best.

However, another relevant question can be raised. What will become of the notion of »free Sunday«? Will the Croatian society stick to the traditional, although by this time somewhat vague, perception of the distinct ethos of Sunday? Will this polarisation of society and the inevitable rise of individualism

in Croatian culture (unpublished doctoral dissertation), Boston, Gordon-Conwell Theological Seminary, 2016. 
turn the idea of Sunday as a day intended for the rest of the entire community into something obsolete, at least for those who are active members of Christian congregations? Perhaps people as individual believers will still choose to practice some activities traditionally associated with Sunday, although the pressure and availability of activities deprived of a specifically religious character could continue to grow.

\section{Conclusion}

Although there are, without doubt, multiple ways of its interpretation, this Campaign can be read as a particular example of the historical church located in a situation where it began »losing [its] capacity to discipline the religious thinking of large sections of the population. $«^{45}$ In order to become able to articulate and raise its voice in the public arena, this particular church must resort to a different religious economy and encourage voluntarism in its members. As their participation in Free Sunday Campaign unfolds, it becomes more evident that their belonging to the Church can no longer be based exclusively on the sense of obligation. Instead, it is upgraded and made manifest through making specific decisions and taking a stand that might have public and ethical consequences. Although the current condition of Campaign's cause is precarious, the Campaign itself served as a crucial predecessor to other initiatives based on a similar appreciation of lay involvement.

Finally, in my opinion, this Campaign shows that whether the Catholic Church will remain relevant force in this society can depend on at least several factors: (1) its authentic expression in public is fostered by engagement of those believers who perceive themselves as members on the basis of their free choice and who are guided by their firmly held convictions; (2) the likeliness of more general approval of Church's advocacy increases with its capability of promoting solidarity with those who would benefit from a particular social cause; and (3) the justifiability of Church's efforts to contribute to the wellbeing of entire society can be evaluated simply by establishing how integrative, healing and restoring are the effects of its efforts. Perceived through this prism, Free Sunday Campaign might provide invaluable insights for years to come.

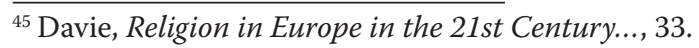




\section{Enoh Šeba* \\ Kampanja za neradnu nedjelju - studija slučaja \\ Sažetak}

Nakana ovoga članka jest analizirati kampanju za neradnu nedjelju koju su u Hrvatskoj 2003. godine pokrenuli Hrvatski caritas i Franjevački institut za kulturu mira u suradnji s nekoliko većih sindikalnih organizacija i Centrom za promicanje socijalnog nauka Crkve. Autor prati tijek kampanje u razdoblju od njezinih početaka pa sve do posljednjeg ukidanja zabrane rada nedjeljom 2009. godine tako da analizira teološke i etičke razloge koji funkcioniraju kao temeljna motivacija kampanje, predstavlja njezinu operativnu metodologiju i istražuje njezine zadane i postignute ciljeve. Potom se kratko razmatra i desetogodišnje razdoblje (2009-2019) u kojemu se nastoji oživjeti napore za zabranu rada nedjeljom i u kojemu osniva Hrvatski savez za nedjelju. U kratkom osvrtu na neke novije društveno angažirane inicijative koje su pokrenule različite udruge i grupe povezane s Katoličkom crkvom, autor tvrdi da je kampanja za neradnu nedjelju uspješno otvorila društveni prostor i pokazala put koji mogu dalje krčiti društveno zauzeti vjernici-laici i građani osjetljivi na društvene nepravde. Istodobno, autor ukazuje i na manji potencijal kasnijih inicijativa (Hod za život, U ime obitelji) da ostvare kohezivan učinak u hrvatskome društvu čije je tkivo trenutno ozbiljno nagriženo polarizacijskim trendovima, te propituje njihov izbor etičkih pitanja koja nastoje adresirati svojim javnim djelovanjem. Konačno, iznosi se i zaključak prema kojemu je kampanja za neradnu nedjelju uspješno naznačila da će autentičnost društvene prisutnosti Katoličke crkve ubuduće sve više ovisiti o laičkom angažmanu, o djelotvornom promicanju solidarnosti s onima koji podnose izrabljivanje, kao i o jasnim dokazima da njezini napori doprinose cjelovitosti i ozdravljenju društva (a ne unošenju dodatnih podjela).

Ključne riječi: laički angažman, neradna nedjelja, Savez za slobodnu nedjelju, solidarnost, voluntarizam.

\footnotetext{
* Dr. sc. Enoh Šeba, tajnik Sveučilišnog centra za protestantsku teologiju Matija Vlačić Ilirik Sveučilišta u Zagrebu, Ivana Lučića 1a, HR-10000 Zagreb; E-mail: enoh.seba@tfmvi.hr.
} 